KS. GRZEGORZ BUJAK* - LUBLIN

\title{
PRACA SPOŁECZNA W DIECEZJI KIELECKIEJ W ŚWIETLE PUBLIKACJI NA LAMACH „KIELECKIEGO PRZEGLĄDU DIECEZJALNEGO” W LATACH 1926-1939. ZARYS PRZEMIAN
}

W wyniku podpisania konkordatu z 1925 r., który ustalił ogólne ramy funkcjonowania Kościoła katolickiego w państwie i wytyczenia nowych granic diecezji, doszło w Polsce do okrzepnięcia podstawowych struktur, mających decydujący wpływ na systematyczne i pogłębione oddziaływanie katolicyzmu na społeczeństwo polskie. Dobiegał końca okres pewnego fermentu i niepokojów spowodowanych wojną, rewolucją i wydarzeniami pionierskiego okresu niepodległości. Sytuacja Kościoła stabilizowała się i podobnie było z podejściem katolików, w tym szczególnie duchowieństwa, do kwestii społecznej. Była ona zagadnieniem stosunkowo nowym w doktrynie kościelnej i jeszcze nowszym w świadomości duchowieństwa diecezji kieleckiej. Te aspekty zostały przeze mnie omówiony w poprzednim artykule ${ }^{1}$. Obecnie skupię się na zarysowaniu zmian w kierunkach podejścia do kwestii społecznej od 1926 r. do wybuchu II wojny światowej. Podstawą będzie analiza publikacji zawartych na łamach miesięcznika dla duchowieństwa „Kieleckiego Przeglądu Diecezjalnego” (dalej: KPD).

Omawiany okres rozpoczął się od ważnego wydarzenia politycznego, które wstrząsnęło duchowieństwem nie tylko kieleckim, był nim przewrót majowy. Tamte wydarzenia stały się podstawą niepokojących obserwacji i analiz dotyczących stanu zakorzenienia katolicyzmu i Kościoła w społeczeństwie. Wyrażały one różnorodne obawy dotyczące oceny dotychczasowej działalności duchowieństwa, w tym także społecznej i założeń na przyszłość.

Na łamach KPD, nie znajdziemy wielu odniesień do przewrotu majowego. Co mogło być spowodowane zaskoczeniem i początkowo głębokim zaniepokojeniem o przyszłość. Powszechnie był znany nieprzychylny stosunek bpa A. Łosińskiego

* Ks. Grzegorz Bujak - dr hab. historii; adiunkt w Katedrze Ustroju i Administracji Polski, Instytut Historii KUL; e-mail:gbujak@kul.pl

${ }^{1}$ G. Bujak, Praca społeczna $w$ diecezji kieleckiej $w$ świetle publikacji na łamach miesięcznika dla duchowieństwa, „Przegląd Diecezjalny” z lat 1917-1925, s. 5-24. 
do J. Piłsudskiego i napięcia jakie z tego powodu istniały w diecezji kieleckiej². W tamtym czasie ukazał się jednak pewien szczególnie ważny artykuł. Nie dotyczył on samego przewrotu, ale wydarzeń jakie w związku z tym miały miejsce w kilku parafiach diecezji. W numerze PKD z czerwca/lipca 1926 r. została zamieszczona relacja z zamieszek w Szczekocinach z 24 maja tamtego roku.

Ks. E. Gielniewski relacjonował wydarzenia, których osobiście co prawda nie był świadkiem, ale jak stwierdzał, znał je z „wiarygodnego źródła”. Chodziło o wiec polityczny, podczas którego, jak stwierdzał autor, lokalni radykalni działacze z PSL „Wyzwolenie” (m. in. S. Bekier i J. Ledwoch) nawoływali chłopów do wykorzystania zajść w Warszawie i krwawej rozprawy z dziedzicami i duchowieństwem, a także przejmowania ziemi dworskiej i lasów. Obiecywali oni broń dla chłopów i zapewniali, że taki zryw spotka się z akceptacją J. Piłsudskiego po jego wyborze na prezydenta, gwarantowali też, że wojsko nie podejmie działań przeciw tym akcjom ${ }^{3}$. Nadzieje agitatorów okazały się przedwczesne. J. Piłsudski wyboru na stanowisko nie przyjął a policja aresztowała kilku uczestników zamieszek. Jednak sam wiec, jak i późniejsze lokalne tumulty, spotkały się z przychylnym zainteresowaniem i poparciem wielu przedstawicieli ludności chłopskiej.

Wychodząc od tych wydarzeń autor rozwijał refleksje o sytuacji społecznej na wsi i zmianach $w$ tym zakresie. Odnotował, że zamieszki spotkały się z ,przerażeniem" lokalnego duchowieństwa, ale kiedy bezpośrednie zagrożenie minęło należało jego zdaniem, podjąć refleksję nad tym co się stało. Zauważał, że w psychice ludu, od wieków katolickiego „objawiła się poważna rysa, nad którą nie możemy przechodzić do porządku dziennego”. Jego zdaniem chłopi „bardzo łatwo dali się pociągnąć do bolszewickich metod działania, że w nich bez trudu można rozpętać złe zwierzęce instynkty”. Wskazywał, że obowiązkiem księży jest tak wychowywać lud, aby nie ulegał łatwo podszeptom agitatorów i dokonywał właściwych moralnie wyborów. Przestrzegał, że gdy w przyszłości dojdzie do zamieszek, to będzie za późno na oddziaływanie i z sarkazmem przewidywał reakcję duchowieństwa:

Nie wykrzeszemy w sobie wtedy silnej odwagi, aby wystąpić jawnie przeciw wzburzonemu ludowi, ograniczymy się do wewnętrznego bólu serca i do przypatrywania się z ubocza, jak fala życia popłynie na bezdroża ${ }^{4}$.

W związku z tym wzywał do podjęcia zawczasu pewnych działań i przekonywał, że „przynęty chciwości majątkowej” nie są nieodparte, i można im przeciwdziałać. Rozwiązanie widział w wychowaniu moralnym włościan, podkreślał jednak, że będzie to proces długotrwały. Zarzucał księżom zaniechania w pracy „nad ludem” w dawnych spokojniejszych czasach i brak zrozumienia dla kwestii społecznych. Był to wyraźny przytyk do tych duchownych, którzy w minionym okresie torpedowali społeczne zaangażowanie kleru. W ten sposób wytrącał z ręki

${ }^{2}$ K. Krasowski, Biskupi katoliccy II Rzeczypospolitej. Stownik biograficzny, Poznań 1996, s. $151-152$.

${ }^{3}$ E. Gielniewski, Groźne przestrogi dni majowych, „Kielecki Przegląd Diecezjalny” (dalej: KPD), 13 (1926) nr 6-7, s. 112.

${ }^{4}$ Tamże, s. 113-114 
broń, jak się wydaje, wciąż licznym zwolennikom tradycyjnej roli księdza i wywierał moralny nacisk, czyniąc ich w pewnym sensie współodpowiedzialnymi zaistniałego kryzysu. Bez retorycznej zapewne przesady przypominał zarzuty stawiane w przeszłości pod adresem księży społeczników: „Po co nam jakaś dodatkowa praca, poza zwykłymi tradycyjnymi zajęciami parafialnymi. Licho nadało tych niespokojnych duchów, że też to chce im się fatygować i czas tracić przy dodatkowych zajęciach. Przewidują jakieś trudne czasy - to są pesymiści z urojenia, mylą się bardzo. I wszystko szło tradycyjną, utartą drogą"5.

Dalej następowały szczegółowe opisy zaniedbań w nauczaniu kościelnym i katechezie. Autor stwierdzal, że oferowane w nich „okruchy” nauczania nie mogły wystarczyć ludowi w starciu z falą działań agitatorów. Przypominał, że kontrola ze strony państwa carskiego w poprzednim okresie sprzyjała minimalizmowi działań księży i odzwyczaiła ich od podejmowania większych wysiłków. Następnie przekonywał, że w chwili obecnej „tradycyjna ilość pracy nad chrześcijańskim charakterem ludu" jest niewystarczająca, podjęcie dodatkowej pracy społecznej jest koniecznością i wskazywał na kierunki działań do których realizacji wzywali księża-działacze już co najmniej od 1917 r. Chodziło mu m. in. o tworzenie katolickich stowarzyszeń młodzieży i dorosłych, oraz rozwój czytelnictwa odpowiedniej prasy i książek. Przypominał, że lewicowi agitatorzy dostrzegali znaczenie wpływu kleru na lud, gdy nakazywali na wiecach, aby „księży pilnować”, uniemożliwiać im kontakty między sobą i z dworami. Ks. E. Gielniewski, którego ostre pióro nie raz wytykało duchowieństwu ospałość wzywał do zwarcia szeregów i mobilizacji w celu działań na polu społecznym.

Podobnych wystąpień, znajdziemy wiele w tamtym czasie na łamach KPD. Były one wyrazem przekonania wyższego duchowieństwa diecezji z biskupem na czele o wciąż niewystarczającym zaangażowaniu księży w nowe formy oddziaływania na wiernych. Celem tych publikacji była stała mobilizacja duchowieństwa. Oddziaływanie takie dokonywało się także w terenie. Referenci kurialni, lub za inspiracją władzy duchownej przedstawiciele lokalnego duchowieństwa, wygłaszali na konferencjach dekanalnych referaty podobne w treści, a czasem nawet bardziej ostre niż artykuł ks. E. Gielniewskiego.

Przykładem może być referat wygłoszony na konferencji w Irządzach w dniu 16 sierpnia 1926 r., a opublikowany w KPD w roku następnym. Jego autorem był nie wymieniony z nazwiska duchowny, z kontekstu wynika, że starszy wiekiem, być może dziekan dekanatu. Prelegent rozpoczynał od wyliczenia wad moralnych ludu wiejskiego. Zauważał, że istniejący pewien zewnętrzny respekt dla autorytetu Kościoła, w praktyce nie wpływa na poziom moralności wiernych. Stwierdzał, że wśród ludu dominuje wybiórcze podejście do praktyk religijnych i wymogów moralnych, oraz kierowanie się $\mathrm{w}$ tym względzie indywidualizmem a nie nauczaniem Kościoła:

\footnotetext{
${ }^{5}$ Tamże, s. 115.
} 
ślepe hołdowanie osobistym przywidzeniom i dowolne komentowanie poszczególnych zasad życia, biegunowo sprzecznych z ideałami, które Chrystus Pan zostawił nam w spadku'.

Autor przytaczał wiele przykładów takiej postawy. Do najważniejszych zaniedbań zaliczał lekceważenie cudzej własności:

Utrwaliło się też przekonanie, że prawo własności istnieje tylko dla chłopa, natomiast wyjmuje on spod tego prawa każdego większego właściciela i traktuje go, jako nieprawego posiadacza swojej własności. W jego pojęciu ziemia jest niesprawiedliwie podzielona i zachodzi potrzeba skorygowania dotychczasowych porządków ${ }^{7}$.

Duchowny z zaskoczeniem stwierdzał dalej, że chłopi byli przekonani o słuszności takiego postępowania i same ich poglądy uważał za przestępstwo: „I co jest arcyniedobrym, że sprawcy tych przestępstw, wyznawcy tych niechrześcijańskich zasad, są przekonani o swojej słuszności, czyli, że te antyludzkie i antychrześcijańskie zasady powoli zyskują wśród ludu prawo obywatelstwa"8.

Wyprowadzał z tego wniosek, że do skutecznego duszpasterstwa dziś już „nie wystarcza ambona i konfesjonał”. Zamknięcie się w murach kościoła było przez wiernych uważane za zachowanie ,urzędowe” i jako takie, nie cieszyło się większym szacunkiem. Przekonywał, że jeśli księża odwrócą się w sprawach społecznych od wiernych w tę lukę wejdą wrodzy agitatorzy: ,ktoś inny nas uprzedzi i dla swoich przekonań pozyska". Za główną przyczynę zmian w świadomości wiernych uważał ,agitację żywiołów socjal-ludowcowych”, po czym w pozytywnym wykładzie przypominał tradycyjną naukę Kościoła o kwestii własności ${ }^{9}$.

Nie wykluczał jednak poparcia dla reformy rolnej i krytykował ziemiaństwo za jego egoizm grupowy w rozwiązywaniu problemu głodu ziemi na wsi:

jesteśmy zwolennikami a nie przeciwnikami reformy rolnej wbrew szczuciu różnych demagogów, i o tym chłop winien pamiętać. Tym bardziej poprzemy reformę tę, że większość właścicieli swoim egoizmem i fałszywym pojęciem, że własności swojej wolno nawet nadużyć, wzbudza stale zazdrość i pożądanie upośledzonych ${ }^{10}$.

Dalej stwierdzał, że taka postawa ziemiaństwa była w sprzeczności z nauczaniem Kościoła i odwoływał się do encykliki Rerum novarum:

Taka etyka materialistyczna, nie uznająca niewygodnych dla siebie więzów społecznych i obywatelskich, odmawiająca wszystkiego bliźnim, a więc i prawa do życia na stopie godnej człowieka, musi być przez przedstawicieli Kościoła zwalczana jako występek, przeciwny prawu Bożemu ${ }^{11}$.

By przekonać duchowieństwo o potrzebie podjęcia pracy społecznej wśród ludu wiejskiego uciekał się i do innych argumentów:

${ }^{6}$ Projekt akcji religijno-społecznej dla duchowieństwa $w$ dobie obecnej, KPD 14, (1927) nr 3, s. 57.

${ }^{7}$ Tamże.

${ }^{8}$ Tamże, s. 58.

${ }^{9}$ Tamże, s. 58-59.

${ }^{10}$ Tamże, s. 59.

${ }^{11}$ Tamże. 
Potrącić by można i o względy osobiste, które nam dyktują poparcie kmiotka, bo przecież nie panowie, ale on nas utrzymuje. Nie podrzyna się gałęzi, na której się siedzi. Będzie to argument natury nazbyt osobistej, ale może nawet bardziej przekonywujący ${ }^{12}$.

Po tym wskazaniu na naturalny związek łączący pasterzy z wiernymi, wyjaśniał wykorzystywane często w walce z księżmi przez „rycerzy przewrotu” sporne kwestie dotyczące opłat dla duchowieństwa i szerzej kosztów utrzymania księży. Argument ten rzeczywiście pojawiał się w wystąpieniach agitatorów wywodzących się z kręgów radykalnie ludowych i co należy podkreślić, często zyskiwał przychylność słuchaczy. Prelegent stwierdzał to z rozczarowaniem i dodawał wyjaśniając, czego ,otumanieni agitacją radykalną” chłopi nie dostrzegają:

Taki człowiek nie widzi naszej darmowej pracy w konfesjonale, na ambonie, w licznych nabożeństwach, katechizacji dzieci, jazdach do chorych, w instytucjach społecznych, słowem w całorocznej pracy żmudnej i wyczerpującej ${ }^{13}$.

Podsumowując omówione poglądy, trudno nie zauważyć, że odzwierciedlały one napięcia $\mathrm{i}$ dylematy $\mathrm{w}$ podejściu do rozumienia kwestii społecznych nabrzmiewających na polskiej wsi od wielu pokoleń właściwe nie tylko dla księży diecezji kieleckiej. Dla większości księży narastający spór socjalny był zaskoczeniem. Próbowali go zrozumieć i rozwiązać wychodząc z tradycyjnych koncepcji, w tym także nauczania papieskiego wzywającego do postawy solidarystycznej między grupami społecznymi i w większości z góry odrzucali jakiekolwiek inne interpretacje. Wbrew ich oczekiwaniom nie zyskiwało to szerszego zrozumienia tak wśród ziemian, jak i chłopów.

Cytowane wystąpienie odzwierciedlało właściwe dla epoki zakłopotanie duchowieństwa w starciu $\mathrm{z}$ dynamiką napięć społecznych na wsi, a jego efektem było poszukiwanie winnych zaistniałych problemów w przedstawicielach ruchów radykalnych. W referacie czytamy:

Przewrotna agitacja w słowie i w druku dąży do skomunizowania tłumów i pchnięcia ich do grabieży dworów i plebanii. (...) Dziś sytuacja jest zagadkowa, jutro tak niewyraźne, że byłoby wprost zdradą wobec Kościoła i ojczyzny nic nie przedsięwziąć. Wszak dziś masoneria, socjalizm i żydostwo protegują te czynniki antyreligijne i antyspołeczne, które dążą do bolszewizmu u nas pod hasłem: przecz z panami i księżmi.

Jeden ze sposobów zapobiegania rozwojowi nastrojów radykalnych, autor widział w utrzymywaniu bliskich więzi duszpasterzy z wiernymi. Przypominał zwyczaj niedzielnych wyjazdów księży po nieszporach do okolicznych wiosek, aby tam spotykać się z parafianami i z przekonaniem stwierdzał, że wierni takich kontaktów potrzebują. Te bezpośrednie formy kontaktu miały służyć łagodzeniu wrażenia „urzędowości duszpasterzowania” i temu aby lud zrozumiał, że „ksiądz naprawdę jest ojcem duchownym”. Przy okazji takich spotkań zachęcał do rozda-

\footnotetext{
12 Tamże.

13 Tamże, s. 60.
} 
wania dzieciom obrazków świętych, a starszym broszurek „ciekawej i pożytecznej treści"14.

Wiele uwagi poświęcił referent złym skutkom oddziaływania prasy radykalnej, której prawdziwą „trucizną” było według niego „bezczeszczenie za pomocą kłamstwa wszystkiego, co drogie sercu każdego katolika i dobrego Polaka". Równocześnie zauważał że prasa katolicka taka jak „Ojczyzna”, „Zorza”, czy „Przewodnik Katolicki”, nie są wystarczające do walki z tak groźnym przeciwnikiem. Po czym przechodził do obszernego wykładu na temat nieistniejącego już tygodnika „Rola”, którego dorobkiem chciał zainteresować słuchaczy, oraz zasług jego redaktora Jana Jeleńskiego. Wskazywał, że podejście tamtego środowiska redakcyjnego z przełomu wieków powinno być inspiracją dla dzisiejszych działań księży. W referacie czytamy:

Przez 24 lata śledziłem działalność Jeleńskiego i stwierdzam, że niezrównany ten szermierz katolicki i narodowy dławił z takim skutkiem bandytów gazeciarskich, szachrai giełdowych, demoralizatorów, żydolubstwo wielkich panów, oportunizm czołowych osobistości, że nie było wypadku, żeby nie poskromił, nie przeciął dziennikarską piłą nadużycia, które zdusić postanowił. Antysemityzmu polskiego jest twórcą Jeleński. (...) Takiego redaktora, takiej gazety nam potrzeba. Nie bąknięcia kiedy niekiedy w stronę napastnika, ale nieustannego, nieubłaganego wyświetlania prawdy. Pismo takie byłoby chętnie przez kmiotków czytane, choćby dlatego, że mieliby gotową odpowiedź na wszystkie bałamuctwa rozsiewane na księży, na Kościół, na narodowo myślących Polaków ${ }^{15}$.

Powyższy fragment referatu ma szczególne znaczenie, gdyż co prawda był on wygłoszony do wąskiego kręgu duchowieństwa w typowo wiejskim dekanacie, jednak jego zamieszczenie w piśmie docierającym do całego duchowieństwa diecezji wskazywało na akceptację jego treści przez kręgi wyższego duchowieństwa. Wskazywanie na masonerię, socjalizm i w tym kontekście Żydów, jako nie tylko wrogów Kościoła i ojczyzny, ale szerzej sprawców problemów w zmaganiu się Polski odrodzonej z rzeczywistością, nie należało do poglądów odosobnionych wśród księży. Akcenty antysemickie pojawiały się na łamach KPD zarówno w przeszłości, jak i później. Jednak ich natężenie ilościowe i ostrość w okresie bezpośrednio po maju 1926 r. zasługują na głębszą analizę wykraczającą poza ramy niniejszej publikacji.

Uwrażliwianie duchowieństwa na możliwość realizacji w Polsce radykalnego scenariusza społecznego, podobnego rosyjskiemu, służyło jego mobilizacji do większego wysiłku w pracy społecznej w obliczu zagrożenia. Przy okazji różnych zjazdów i konferencji władza diecezjalna zachęcała do większych działań w tym kierunku. Przykładem może być konferencja księży miasta Kielc z 1926 r., podczas której jeden z prelegentów wzywał do powstania organizacji mającej skupić rozproszone wysiłki katolików:

Obóz katolicki składa się dziś z wielu dobrych i żądnych pracy jednostek, brak nam jednak jest ludzi zdecydowanych i świattych. Stworzenie Ligi Ka-

\footnotetext{
${ }^{14}$ Tamże.

${ }^{15}$ Tamże, s. 62.
} 
tolickiej zaradziłoby prawdopodobnie scentralizowaniu się myśli katolickiej, a $\mathrm{z}$ jednostek, w gruncie rzeczy prawych, lecz odosobnionych i chodzących luzem - uczyniłoby silny blok katolicki, z którym musiałby się liczyć i rząd i społeczeństwo ${ }^{16}$.

Utworzenie zwartej jednolitej organizacji katolickiej o tak szerokim spektrum oddziaływania stawało się w coraz większej mierze celem władzy diecezjalnej. Zagadnienie powołania Ligi Katolickiej organizowanej na wzór poznański, ale równocześnie podporządkowanej wyłącznie biskupowi diecezjalnemu, a nie organizacjom ponad diecezjalnym, pojawiało się już wcześniej i znalazło nawet swój wyraz w postanowieniach synodu kieleckiego z 1927 r. ${ }^{17}$. Ostatecznie jednak, zwyciężył w Polsce program tworzenia organizacji o charakterze ogólnopolskim znanej jako Akcja Katolicka, który gwarantując biskupom diecezjalnym znaczne prerogatywy, odwoływał się do koncepcji organizacji skupiającej wysiłki katolików na poziomie ogólnokrajowym. Program ten został ostatecznie przyjęty na konferencji episkopatu w 1930 r. $^{18}$

Już pod koniec 1929 r. na łamach KPD, w relacji z konferencji księży dziekanów z 21 listopada, został zawarty zarys programu działalności Akcji Katolickiej w diecezji na rok 1930. Program oparty był na zasadach Akcji Katolickiej, jako organizacji ogólnopolskiej. Od tego czasu termin Liga Katolicka przestał występować w publikacjach na łamach miesięcznika.

Jednym z referentów na konferencji księży dziekanów był ks. A. Błaszczyk. Na wstępie swojego wystąpienia przedstawił dychotomiczną wizję współczesności, w której jego zdaniem, „neopogaństwo” staje naprzeciw „nauki Chrystusa”, głoszonej przez Kościół rzymsko-katolicki. Odwołując się do encyklik społecznych zauważał, że do walki z tym wrogiem wezwani są nie tyko biskupi i księża, ale także świeccy. Działalność tego zwartego frontu miała obejmować akcję religijną, obyczajową, oświatową i dobroczynną. Prelegent wzywał do oparcia tej pracy na bractwach różańcowych, trzecim zakonie i stowarzyszeniach młodzieży istniejących już w niektórych parafiach. Pod tym względem referat był powtórzeniem podobnych wezwań z przeszłości. Liczono na to, że szybki rozwój Akcji Katolickiej w diecezji uda się oprzeć na członkach wywodzących się z parafialnych organizacjach dewocyjnych, które chciano wykorzystać jako swoiste zaplecze ludzkie do tworzenia nowej organizacji. Już bowiem szczegółowe założenia pracy na rok 1930 wskazywały, że nacisk zostanie położony na działalność o charakterze społecznym, a nie czysto dewocyjnym ${ }^{19}$.

Kolejny referent ks. M. Połoska w swoim wystąpieniu informował, że w diecezji działało 153 stowarzyszenia młodzieży „rokujące piękną przyszłość”. W zaleceniach pracy na rok 1930 r. przewidywał utworzenie takich stowarzyszeń we wszystkich parafiach diecezji. W czasie konferencji dziekani podjęli zobowiązanie, aby „utrzymać biuro i pracownika dla Akcji Katolickiej”. Była to ważna

\footnotetext{
${ }^{16}$ Sprawozdanie z pierwszej konferencji pasterskiej kapłanów m. Kielc, KPD, 14 (1927) nr 1,
} s. 25.

${ }^{17}$ Synodus Dioecesana Kielcensis, Kielce 1927, stat. 329.

${ }^{18}$ R. Niparko, Akcja Katolicka, „Encyklopedia Katolicka”, t. 1, Lublin 1985, kol. 229.

${ }^{19}$ Sprawozdanie z konferencji Ks. Dziekanów, KPD 16 (1929), nr 12, s. 295-296. 
deklaracja, podjęcia przez księży stałego, zbiorowego wysiłku finansowego na rzecz utrzymania duchownego, który otrzymywałby wynagrodzenie za kierowanie Akcją Katolicką w diecezji. Wcześniejsze podobne próby nie powiodły się ${ }^{20}$.

W ślad za tymi decyzjami w numerze KPD ze stycznia 1930 r. zostało zamieszczone polecenie kurii, aby zagadnienie Akcji Katolickiej zostało omówione w każdym dekanacie na konferencjach księży. Zachęcano, aby w wystąpieniach korzystać z licznej już literatury dotyczącej tej organizacji. Szczególnie polecano broszurę ks. S. Adamskiego „Akcja Katolicka a duchowieństwo”, oraz cykl artykułów na łamach „Gazety Kościelnej” z 1929 r. „Akcja Katolicka u podstaw i w praktyce" 21 .

W kolejnym numerze KPD ukazała się informacja o rozpoczęciu wydawania diecezjalnego periodyku pod nazwą „Gazeta Tygodniowa”, który miał być „koniecznie potrzebny dla energicznego i planowego poprowadzenia Akcji Katolickiej w diecezji”. Miał on być „orężem nowoczesnym dla wyrabiania dusz chrześcijańskich”. Był on przeznaczony w pierwszym rzędzie dla księży, którzy jednak mieli zajmować się jego kolportażem wśród świeckich. Pomny tego, że podobne akcje prenumeraty za pośrednictwem parafii w przeszłości często kończyły się fiaskiem ks. S. Cieśliński z naciskiem pouczał, że czasopismo to „musi pójść pomiędzy lud..., do rąk..., do oczu..., do umysłów..., do serc..., a nie zalegać broń Boże w paczkach nierozpieczętowanych po kątach kancelarii parafialnych". Nie pominął przy tym informacji, że „Gazeta Tygodniowa” powstaje na życzenie biskupa, co miało zachęcić księży do kolportażu. Zachęcał, aby do redakcji nadsyłano informacje o działalności Akcji Katolickiej w parafiach, a do pisania w tygodniku zapraszał również świeckich ${ }^{22}$.

Na zjeździe księży dziekanów z 29 kwietnia 1930 r. omawiano inne aspekty związane z tworzeniem w diecezji Akcji Katolickiej. Ks. A. Błaszczyk w następujący sposób wyjaśniał zebranym na czym polega udział członków Akcji Katolickiej w hierarchicznej posłudze Kościoła: „Akcja Katolicka, która niczym innym nie jest, jak udziałem świeckich w apostolstwie hierarchicznym Kościoła katolickiego dla obrony zasad religii i moralności oraz dla rozwoju zdrowej i pożytecznej akcji społecznej pod przewodnictwem hierarchii kościelnej, ponad wszystkimi partiami politycznymi i niezależnie od nich, celem odnowienia życia katolickiego w rodzinie i społeczeństwie". Jako cel działania organizacji wskazywał, że miała ona:

zwalczać cywilizację antychrześcijańską i na jej miejsce wprowadzać zasady Chrystusowej, Bożej nauki. (...) winna zmierzać nieustannie ku temu, by prawa publiczne były zgodne z wolą Bożą, by w należyty sposób zostały respektowane prawa Kościoła ${ }^{23}$.

${ }^{20}$ Tamże, s. 296-297.

${ }^{21}$ Instrukcja o konferencjach dekanalnych w roku 1930, KPD, 17 (1930) nr 1, s. 7-8.

${ }^{22}$ S. Cieśliński, O poparcie dla powstającej diecezjalnej „Gazety Tygodniowej, KPD, 17 (1930), nr 2, s. 38-39.

${ }^{23}$ Zjazd diecezjalny Księży Dziekanów, Wicedziekanów i delegatów dekanalnych, KPD, 17 (1930) nr 6-7, s. 192. 
Dalej prelegent przypominał, że nie wszystkie organizacje kościelne mogą należeć do Akcji Katolickiej:

Nie należą tu bezpośrednio tzw. organizacje o charakterze religijno-dewocyjnym, choć mogą oddać nieocenione usługi pomocnicze (...) natomiast $\mathrm{z}$ wyjaśnień Stolicy Apostolskiej wynika, że należą organizacje o charakterze świeckim jak Stowarzyszenia Młodzieży Polskiej i Katolicki Związek Polek ${ }^{24}$.

Kolejny referat ks. A. Sobczyńskiego „Akcja Katolicka w diecezji kieleckiej” przedstawiał cele działania centrali Akcji Katolickiej, która miała być powołana przy kurii: „Głównym zadaniem Centrali Diecezjalnej będzie 1. uświadamianie kapłanów i wiernych, 2. oddziaływanie na osoby i zespoły celem wytworzenia tzw. elity katolickiej, 3. oddziaływanie na wiernych, czyli elity na masy". Zdaniem prelegenta elitę należało wyszukiwać spośród członków już istniejących w parafiach organizacji katolickich o charakterze religijno-dewocyjnych, aby następnie przy ich udziale tworzyć nowe organizacje działające w ramach parafialnej Akcji Katolickiej. Dla kształcenia elit katolickich zalecał: „Tygodnie Akcji Katolickiej, które będą obejmowały rekolekcje zamknięte; wykłady dyskusyjne z dziedziny Akcji Katolickiej, referaty na rozmaitych zjazdach i kongresach tercjarzy, różańcowych oraz na zlotach Stowarzyszeń Młodzieży płci obojga”. Na masy wpływać miano przez „urządzanie dni: rodziny, papieskich, prasy, Chrystusa Króla". Zadania Centrali miały być bardzo rozległe i obejmować troskę: „o rodzinę, wychowanie, szkołę, sprawę Kościoła, dobrą prasę itd”. Ponieważ organizowanie $\mathrm{w}$ diecezji struktur terytorialnych przewidzianych przez „Statut Akcji Katolickiej w Polsce", w tym rad różnego szczebla, miało zająć sporo czasu, decydującą rolę w rozwoju Akcji Katolickiej w diecezji w początkowym okresie miała odegrać Centrala Diecezjalna. Za organizacje przygotowane do wejścia w skład Akcji Katolickiej, ks. A. Sobczyński uznawał „Stowarzyszenie Młodzieży Męskiej i Żeńskiej, oraz Katolicki Związek Polek", natomiast w odniesieniu do organizacji dewocyjnych, podobnie jak poprzedni referent stwierdzał, że „nie wchodzą w zakres hierarchicznego apostolstwa świeckich, mogą jednak oddać wyśmienite usługi Akcji Katolickiej, pogłębiając uświadomienie katolickie, wychowując ludzi czynu"25.

Autor trzeciego referatu, ks. S. Cieśliński, rozpoczął od uwagi, która jak się wydaje odzwierciedlała wyobrażenia duchowieństwa diecezji o ówczesnych problemach świata i społeczeństwa: „Dziś ludzkość idzie po linii trzech uniwersalizmów: moskiewskiego czyli bolszewickiego opartego o Azję, londyńskiego opartego o Amerykę, papieskiego opartego o Boga". Następnie w duchu swoich poprzedników mówił o celu Akcji Katolickiej: „Nie jest ona niczym nowym, jest czynem Chrystusa w każdej dziedzinie życia ludzkiego, oraz jest to działanie poza świątynią, choć oparte o świątynię i jej zbawcze wpływy". Wśród praktycznych rozwiązań zalecał uświadamianie duchownych w czasie konferencji dekanalnych w kwestiach dotyczących Akcji Katolickiej. Postulował, aby w parafiach wyszu-

\footnotetext{
${ }^{24}$ Tamże, s. 193.

${ }^{25}$ Tamże, s. 193-195.
} 
kiwać świeckich mężów zaufania i skupić się na ich formacji. Jeśli chodzi o oddziaływanie na ogół wiernych należało ich uświadamiać poprzez „pogłębianie zasad i ideałów Akcji Katolickiej. A kiedy zostanie przeorana gleba ludzkich serc i umysłów można przystąpić do organizowania Komitetu Parafialnego". W dość idealistyczny sposób oceniał możliwości tworzenia w parafiach zaplecza administracyjnego dla organizacji: „Komitet Parafialny musi posiadać własną kancelarię i mieć pewne pomoce techniczne. Sekretarz prowadzi księgi kancelaryjne, księgę protokołów, skarbnik natomiast kasę i księgi kasowe". Tak rozwinięte zaplecze administracyjne dla organizacji sugerowało, że referent oczekiwał, iż stosunkowo wysoki odsetek parafian znajdzie się $w$ jej szeregach. $Z$ drugiej jednak strony zdawał sobie sprawę z tego, że rozwój Akcji Katolickiej w parafiach będzie długotrwały:

Ponieważ Akcja Katolicka to praca na cały szereg wieków, przeto trzeba zabiegać, by już teraz budować ją na mocnych podstawach, a najlepiej to się uczyni, gdy proboszcz weźmie pod swoją opiekę młodzież szkolną, zorganizuje ją w odpowiednie organizacje religijne, następnie po wyjściu ze szkoły skłoni do wstępowania do S.M.P., a wreszcie wychodzącą z S.M.P. skieruje do odnośnych związków katolickich. Wtedy dopiero powstaną zasadnicze cztery piony organizacyjno-stanowe Akcji Katolickiej ${ }^{26}$.

W tym fragmencie wystąpienia ks. S. Cieśliński wskazał na ważny aspekt w podejściu do rozwoju Akcji Katolickiej. Duchowieństwo diecezji kieleckiej widziało w niej przedsięwzięcie rozłożone w czasie, które miało się dokonać wraz $\mathrm{z}$ wymianą pokoleniową. W związku z tym ważną rolę odgrywało kształtowanie wiernych w kolejnych, dostosowanych do ich wieku organizacjach. Dorastając powinni oni przechodzić płynnie z jednej do drugiej. Na ten aspekt czasowy dokonywanej przebudowy społeczeństwa wskazywali już księża w latach 19171925, oni również dostrzegali znaczenie objęcia wiernych ciągłą w czasie formacją w odpowiednich organizacjach. Zaprezentowana przez ks. Cieślińskiego wizja chrześcijańskiego dojrzewania: przechodzenia dzieci w młodzież i w końcu, $\mathrm{w}$ dorosłych wiernych, ale też i obywateli, poprzez uczestniczenie w kolejnych dostosowanych do ich potrzeb i możliwości organizacjach, była istotą cechą Akcji Katolickiej jako narzędzia przebudowy społeczeństwa. Miało to być swoiste narastanie w łonie starego - ocenianego negatywnie przez duchowieństwo - społeczeństwa, nowego o zdecydowanie lepszej kondycji duchowej i moralnej.

Taki cel przebudowy społeczeństwa w skali światowej miał być celem Akcji Katolickiej na co zwracał uwagę papież w swoim nauczaniu. Tak też rozumieli go księża diecezji kieleckiej i do realizacji takiego celu dążyli w zakresie swoich obowiązków, mimo trwających dyskusji, wątpliwości a nawet sporów co do konkretnych rozwiązań. Przykładem tego może być chociażby nieustanne powracanie do sprzecznego z idea Akcji Katolickiej budowania jej w oparciu o organizacje dewocyjne, mające odrębne cele. Widać to było nie tylko w okresie 1917-1925, ale także $\mathrm{w}$ dyskusji bezpośrednio po referacie ks. S. Cieślińskiego w $1930 \mathrm{r}$., kiedy to ks. S. Wiśniewski radził, aby ze względów „,praktycznych” tworzyć:

\footnotetext{
${ }^{26}$ Tamże, s. 195-196.
} 
z istniejących zarządów organizacji katolickich i religijnych jak tercjarstwo, żywy różaniec, stowarzyszenia młodzieży, zręby tego co nazywa się Komitetem Parafialnym Akcji Katolickiej ${ }^{27}$.

W wielu numerach KPD z 1930 r., znajdujemy liczne opracowania omawiające różne aspekty wprowadzania Akcji Katolickiej w diecezji i szczegółowe zarządzenia w tym zakresie. Spowodowało to, jak się zdaje, pewną dezorientację niektórych księży w parafiach jak rozumieć nakładane na nich liczne, nowe obowiązki. W związku z tym w numerze ze stycznia 1931 r. zamieszczono wyjaśnienie kurii co do rangi zarządzeń Komisji Akcji Katolickiej przy kurii. Czytamy w nim:

Akcja Katolicka w dzisiejszych czasach nie jest dobrowolną czynnością, zależną od uznania i gorliwości poszczególnych kapłanów, ale jest pracą obowiązkową wchodzącą ściśle w zakres nowoczesnego duszpasterstwa, do niej jest ściśle zobowiązany każdy duszpasterz na wyznaczonym stanowisku.

Dalej kuria nakazywała wszystkim księżom stosowanie się do zarządzeń komisji i wprowadzanie ich w życie. Wyjaśniano przy tym, że systematyczne zaprowadzanie Akcji Katolickiej w diecezji odbywa się „,stosownie do kategorycznych rozporządzeń Stolicy Apostolskiej i wyraźnych zarządzeń Pasterza diecezji"28 . Było to jasne polecenie skierowane do duchowieństwa które miało przeciwdziałać obstrukcji ze strony przynajmniej pewnej grupy kleru.

Rok 1931 obfitował w publikacje statutów i regulaminów wielu organizacji ważnych z punktu widzenia rozwoju Akcji Katolickiej. Przykładem całkowicie nowej organizacji w diecezji o charakterze społecznym, która odegrała ważną rolę w rozwoju diecezjalnej Akcji Katolickiej, było Stowarzyszenie Pań św. Wincentego A Paulo. Statuty stowarzyszenia i jego Rady Wyższej zatwierdził bp A. Łosiński maju 1931 r. Do końca tego roku opublikowane zostały jeszcze akty normatywne kilku inny organizacji, w tym Regulamin Oddziału Parafialnego Caritas ${ }^{29}$.

Najważniejszy jednak był dekret erekcyjny Diecezjalnego Instytutu Akcji Katolickiej z 19 września 1931 r., jego statut, oraz regulamin Parafialnej Akcji Katolickiej. Statut Instytutu Diecezjalnego stwierdzał m.in., że naczelne kierownictwo sprawuje w nim biskup ordynariusz, a mianowany przez niego Diecezjalny Asystent Kościelny, miał czuwać nad tym, aby działalność Instytutu i całej Akcji Katolickiej w diecezji była zgodna z zasadami Kościoła katolickiego i zarządzeniami biskupa. Ze szczegółowych postanowień na uwagę zasługuje powołanie do istnienia w art. 12 Diecezjalnej Rady Akcji Katolickiej, która miała być organem doradczym i wnioskodawczym DIAK. W jej skład wchodzili prezes i sekretarz DIAK, diecezjalny asystent kościelny, delegaci diecezjalnych stowarzyszeń katolickich, oraz osoby mianowane przez biskupa ${ }^{30}$.

${ }^{27}$ Tamże, s. 197.

${ }^{28}$ Znaczenie zarzadzeń Komisji Akcji Katolickiej, KPD, 18 (1931) nr 1, s. 1.

${ }^{29}$ Statut Stowarzyszenia Pań Miłosierdzia św. Wincentego A Paulo, KPD, 18 (1931) nr 8-9, s. 209-217; Regulamin Oddziału Parafialnego Diecezjalnego Zwiazku Towarzystw Dobroczynności „Caritas” w Kielcach, KPD, 18 (1931) nr 10, s. 229-230.

${ }^{30}$ Dekret Erekcyjny, KPD, 18 (1931) nr 11, s. 263-264; Statut Diecezjalnego Instytutu Akcji Katolickiej w Kielcach, KPD, 18 (1931) nr 11, s. 264-270. 
W tym samym roczniku KPD autorzy w licznych artykułach nawoływali do rozwoju organizacji pomocniczych Akcji Katolickiej. Dla przykładu: krucjatę eucharystyczną zalecano dla uczniów w szkołach powszechnych, a Sodalicję Mariańską wskazywano jako właściwą dla mężczyzn i młodzieży rzemieślniczo-mieszczańskiej²

Ważnym aspektem pracy DIAK była działalność sprawozdawcza i przeprowadzanie ankiet obrazujących różne aspekty życia religijnego w skali całej diecezji. Przykładem takiej ankiety była zapowiedziana już 1929 r., a przeprowadzona w roku następnym ankieta duszpasterska. Fragmenty jej wyników omówione zostały w numerze majowym z 1931 r. i dotyczyły wad "ludu naszego". Na pytanie o te cechy wiernych odpowiadali proboszczowie, bo do nich skierowane było badanie. Za najczęstszą wadę uznawali oni „obłudę i nieufność w stosunku do panów i księży”, w tym własnych duszpasterzy. Dopiero kolejne miejsca zajmowały: pijaństwo (najczęstsze wśród młodzieży), kłótnie, pieniactwo, mściwość i zawziętość, brak poszanowania cudzej własności (pod tym określeniem kryły się kradzieże). Bójki i rozpusta zajmowały dopiero 9 i 10 miejsce $^{32}$. Autor zestawienia opatrywał wyniki obszernymi komentarzami i wskazówkami duszpasterskimi.

W numerze grudniowym zostały omówione fragmenty tej samej ankiety dotyczące życia religijnego młodzieży w parafiach. Jedną z ważnych obserwacji jaką czyniła większości proboszczów, był brak negatywnych skutków pobytu młodych mężczyzn w wojsku. Młodzież wracająca z wojska w niepodległej Polsce nie wykazywała, zdaniem duszpasterzy, objawów demoralizacji, na co często narzekano przed 1918 rokiem w odniesieniu do pobytu w armiach zaborczych. Odnośnie do praktyk parafialnych potwierdzały się znane fakty, że bardziej gorliwe były dziewczęta, niż młodzież męska, a w miesiącach zimowych częściej niż w letnich zaniedbywano obowiązek udziału w mszy św. Odnotowywano także dalszy spadek autorytetu starszych i brak szacunku dla rodziców. Autor opracowania ks. E. Gielniewski zwracał uwagę, że ważnym brakiem w oddziaływaniu na młodzież było zaniedbywanie przez księży współpracy z rodzicami ${ }^{33}$.

W latach 1930-1931 dokonało się w centralnej administracji diecezji uzgodnianie zakresu kompetencji i współpracy między różnymi organami kurii zajmującymi się Akcją Katolicką. Zwieńczeniem tego procesu było posiedzenie Komisji Akcji Katolickiej z 17 grudnia 1931 r., na którym postanowiono, że „Komisja zajmuje się sprawami Akcji Katolickiej niejako od strony duchowieństwa, Instytut zaś i Rada są właściwymi organami Akcji Katolickiej wśród katolików świeckich" 34 .

Ważnym wydarzeniem było pierwsze posiedzenie Diecezjalnej Rady Akcji Katolickiej z grudnia 1931 r. W jej skład wchodzili: Wincenty Turowski prezes

${ }^{31}$ Krucjata Eucharystyczna w szkole powszechnej, KPD ,18 (1931) nr 1, s. 11-13.; W. Jabłoński, O Sodalicje Mariańskie rzemieślniczo-mieszczański, KPD, 18 (1931) nr 1, s. , s. 13-16.

${ }^{32}$ E. Gielniewski, Wady naszego Ludu w świetle duszpasterskiej ankiety zebranej w poczatkach ub. roku, KPD, 18 (1931) nr 5, s. 141-142.

${ }^{33}$ Tenże, Stan religijno-moralny młodzieży $w$ parafiach naszej diecezji na podstawie materiatów z ankiety duszpasterskiej z 1930 r., KPD, 18 (1931) nr 12, s. 307-315.

${ }^{34}$ Z komisji Akcji Katolickiej, KPD, 19 (1932) nr 1, s. 4. 
DIAK, Róża Dobrzańska, Alfred Kehl, Julian Kosicki, Paweł Książek, inż. Julian Messing, Maria Nowroczyńska, Augusta hr. Potocka, Stanisława Roszkowska, inż. Lech Rościszewski, Janina Borowiecka, dr Stanisław Łaszczyński, Zdzisław Wydrychowski, Aleksander Wojtaśkiewicz i ks. Antoni Sobczyński. Spotkanie miało nie tylko charakter organizacyjny. Omawiano na nim program pracy na następny rok. Zebranie to wytyczyło na wiele lat model pracy Diecezjalnej Rady Akcji Katolickiej w diecezji. Podczas tego dorocznego posiedzenia przedstawiciele poszczególnych organizacji wygłaszali referaty, w których omawiali osiągnięcia minionego roku i określali zakres działań na rok następny. Po każdym referacie następowała dyskusja w której uzgadniano wiele szczegółów, wyjaśniano wątpliwości i planowano współpracę między organizacjami.

Wśród referatów wygłoszonych na pierwszym zebraniu rady, na szczególną uwagę zasługuje wystąpienie prezesa W. Turowskiego. Za najważniejsze zadanie w 1932 r. uznał on tworzenie parafialnych ogniw Akcji Katolickiej. Miały temu służyć kursy instruktażowe dla delegowanych z parafii przedstawicieli, oraz oddziaływanie poprzez parafialnych duszpasterzy. Równie ważna jak rozwijanie struktury terytorialnej była praca nad tworzeniem „ognisk skupiających życie katolickie i ułatwiających pracę". Autor miał na myśli budowę domu katolickiego w Kielcach i podobnych budynków w parafiach. Zagadnienie to zajmowało ważne miejsce w planach działań także w kolejnych latach. Pracy nad pogłębianiem życia religijnego wiernych $\mathrm{w}$ parafiach i rozwojowi ruchu społecznego miało służyć dalsze organizowanie bibliotek i czytelni parafialnych, kolportowanie książek i czasopism, oraz działalność odczytowa. Ważną rolę miały odgrywać wspólne manifestacje. Ich celem było skupianie wiernych wokół wybranych inicjatyw i publiczne ukazywanie postaw i poglądów tak religijnych, jak i społecznych. Do najważniejszych inicjatyw w tym zakresie W. Turowski zaliczał obchody kościelnych jubileuszów a wśród głównych celów takiego oddziaływania na lokalne społeczności wskazywał obronę prawd wiary i Kościoła w Polsce przed zakusami wrogów. Konieczność takiej obrony uzasadniał niepokojącymi zmianami w życiu społeczeństwa, które jego zdaniem wymagały szybkiej reakcji. Prelegent stwierdzał: „zastraszający postęp w kierunku laicyzacji naszego społeczeństwa i konsekwentne dążenie do zepchnięcia spraw wiary i Kościoła do rzędu spraw drugorzędnych zmusza społeczność katolicką do wyraźnego manifestowania swego stanowiska" 35 .

W dyskusji jaka się wywiązała po wystąpieniu prezesa DIAK na uwagę zasługuje kilka głosów. Inżynier L. Rościszewski wyrażał obawy, że rozwój Akcji Katolickiej wzmocni działalność sił wrogich Kościołowi. Do tej grupy zaliczał m.in. „,znaczny procent pozytywistycznie nastawionej inteligencji i półinteligencji”. Szczególnie niebezpieczne skutki mogło to przynosić w środowiskach wiejskich. Jako drogę do pozyskania inteligencji wskazywał wspólne rekolekcje zamknięte dla ziemian i nauczycieli. Zauważał, że zapleczem dla takich rekolekcji mogły być dwory i zwracał się do obecnych przedstawicieli ziemiaństwa o podjęcie od-

${ }^{35}$ Protokót z pierwszego posiedzenia Diecezjalnej Rady Akcji Katolickiej w Kielcach dnia 17 grudnia 1931 r., KPD, 19 (1932) nr 1, s. 11-14. 
powiedniej inicjatywy. W odpowiedzi R. Dobrzańska wyraziła obawę, że tylko niewiele dworów posiada odpowiednie warunki dla organizacji takich rekolekcji, a ks. A. Sobczyński zwrócił uwagę, że rekolekcje zamknięte, aby mogły odnieść zamierzony skutek wymagały zgromadzenia uczestników o wyrównanym poziomie intelektualnym, w związku z tym uznawał za konieczne organizowanie osobnych rekolekcji dla ziemian i dla nauczycieli ${ }^{36}$.

Mimo poparcia biskupa dla tworzenia Akcji Katolickiej, księża jeszcze długo wyraźnie ociągali się z akceptacją nowych obowiązków. Świadczy o tym n.p. ponaglenie wystosowane przez Komisję Akcji Katolickiej przy kurii z 1932 r., w którym ze smutkiem stwierdzono, że mimo upływu miesięcznego terminu nadsyłania list osób wyjeżdżających z parafii na Tydzień Akcji Katolickiej, do kurii nie wpłynął ani jeden taki wykaz. W związku z tym komisja nakazywała, aby obowiązkowo z każdej parafii przesłać odpowiedź na to pytanie, także w razie braku osób chętnych do udział w Tygodniu ${ }^{37}$. Obowiązek nadesłania także negatywnej informacji wymuszał na każdym proboszczu ustosunkowanie się do polecenia komisji.

Księża wzbraniali się również przed przyjmowaniem w parafiach świeckich prelegentów Akcji Katolickiej. W odpowiedzi na ich wątpliwości DIAK wydał specjalny komunikat opublikowany na łamach PKD. Wskazywano w nim, że obecność świeckich prelegentów służy pokazaniu wiernym, iż Akcja Katolicka nie jest sprawą tylko duchowieństwa, ale i świeckich. Argumentowano, że Ojciec św. wskazywał jej rozwój jako ,jedynie słuszną i pośrednią między laicyzmem a klerykalizmem drogę". Próbowano przekonywać duchowieństwo parafialne do tego, że nawet jeśli w konkretnej parafii obecnie nie było możliwości spełnienia minimalnych warunków dla powstania tej organizacji (a za takie uważano utworzenie przynajmniej Katolickiego Stowarzyszenia Polaków i Katolickiego Stowarzyszenia Polek) to obecność świeckiego prelegenta ułatwi księżom działania w tym zakresie na przyszłość. Dalej w komunikacie stwierdzano determinację Instytutu w realizacji przyjętych celów: „Będziemy się starali o to, ażeby każdej niedzieli i każdego święta przedstawiciele Instytutu wyjeżdżali z przemówieniami do parafii, które ich zaproszą, albo do tych, do których Instytut ich wprosi”". Przypominano, że parafia, czyli proboszcz osobiście zobowiązany jest do zwrotu kosztów przyjazdu prelegenta ${ }^{38}$.

Bywało też, że DIAK uwzględniał uwagi proboszczów. Księża uważali np., że kursy Akcji Katolickiej powinny odbywać się bliżej ludzi, w terenie a nie w Kielcach. Instytut w odpowiedzi przyjmował ten postulat i zobowiązywał się do przeprowadzania dodatkowo kursów w dekanatach. Równocześnie jednak nie rezygnowano z kursów w Kielcach, tłumacząc, że dla większej grupy uczestników istnieje możliwość zaproszenia „wybitniejszych przyjezdnych prelegentów”. W składzie ekipy wyjeżdżającej na kursy dekanalne miał się znaleźć przedstawiciel Instytutu, oraz dwójka prelegentów świeckich mężczyzna i kobieta. Ich obecność i wystąpienia miały zachęcać do organizowania wspomnianych katolickich

\footnotetext{
${ }^{36}$ Tamże, s. 15.

${ }^{37}$ Z Komisji Akcji Katolickiej. Wykaz osób na Tydzień A. K., KPD 19(1932) nr 6-7, s. 167.

${ }^{38}$ O przyjmowaniu świeckich prelegentów A. K., KPD 19 (1932) nr 8-9, s. 199.
} 
stowarzyszeń kobiet i mężczyzn. Zapowiadano również organizowanie osobnych kursów dla inteligencji, ponieważ: „trudno będzie mieć osobne przemówienie do inteligencji, w czasie ogólnego kursu, gdyż to daje sposobność do nieporozumień, że się wyróżnia inteligencję, jakeśmy już tego doświadczyli" ${ }^{39}$. Ta wypowiedź i wiele innych zamieszczanych na łamach KPD, wskazuje na istniejące napięcia między poszczególnymi grupami społecznymi, co utrudniało rozwój Akcji Katolickiej. Dotyczyło to również napięć między różnymi grupami wiekowymi młodzieży wiejskiej. Niemałą przeszkodą były też antagonizmy między wioskami, które utrudniały gromadzenie $\mathrm{w}$ jednej organizacji stanowej wiernych $\mathrm{z}$ różnych wsi.

Kwestia udziału inteligencji w Akcji Katolickiej stanowiła ważne zagadnienie i była przedmiotem licznych publikacji na łamach KPD. Celem ich było przełamywanie w tym środowisku XIX wiecznych skłonności racjonalistycznych i tworzenie silnej grupy inteligencji katolickiej, która włączyłaby się czynnie w budowanie katolickiego społeczeństwa. Utworzone w tym celu w diecezji kieleckiej stowarzyszenia katolickiej inteligencji męskiej i żeńskiej, nawiązywały do rozwiązań belgijskich. Od początku kwestia katolickiej inteligencji natrafiła na złożone trudności, które w środowisku katolików tak duchownych, jak świeckich, dość jednoznacznie przypisywano działaniom sił wrogich Kościołowi, które zniechęcały elity do otwartego angażowania się w przebudowę społeczeństwa dla Chrystusa.

W związku z tym na posiedzeniu Diecezjalnej Rady Akcji Katolickiej w 1932 r., zaakceptowano decyzję, aby drogą do związania inteligencji z katolicyzmem była Sodalicja Mariańska. Stwierdzano co prawda, że sodalicja nie może wprost należeć do Akcji Katolickiej, ale może odegrać rolę aktywizującą przedstawicieli tej grupy przez to, że: „nie wymagając od członków publicznej działalności apostolskiej, jako organizacja kościelno-religijna, uniknie może sytuacji politycznych i marki antypaństwowych". Przygotowaniem do szerszego rozwinięcia tej akcji miało być zorganizowanie w Kielcach w 1933 r. cyklu wieczorowych konferencji religijnych dla inteligencji w kościele seminaryjnym św. Trójcy. $\mathrm{W}$ dyskusji zauważono znaczne problemy $\mathrm{z}$ aktywizacją inteligencji $\mathrm{w}$ środowiskach małomiasteczkowych. Na pytanie hr. A. Potockiej w tej sprawie, prezes W. Turowski odpowiadał, że większość tamtejszej inteligencji związana była służbowo z władzą państwową a ta była często nieprzychylna inicjatywom Akcji Katolickiej. W tej sytuacji nadzieję widział w rozwijaniu Sodalicji Mariańskiej inteligencji i przeprowadzaniu rekolekcji zamkniętych dla tej grupy ${ }^{40}$.

Już w 1932 r. na posiedzeniu Diecezjalnej Rady Akcji Katolickiej, zwrócono uwagę na kwestię robotniczą. Ks. A. Sobczyński zasugerował konieczność utworzenia związków robotniczych na wzór stowarzyszeń inteligencji katolickiej. Problemem był jednak związek kwestii robotniczej z ekonomiczną i polityczną,

${ }^{39}$ Kursy dekanalne A. K., KPD 19 (1932) nr 8-9, s. 200-201.

${ }^{40} Z$ komisji Akcji Katolickiej. Protokót z drugiego posiedzenia Diecezjalnej Rady A. K. w Kielcach dnia 29 listopada 1932 r., KPD, 20 (1933) nr 1, s. 11-16. 
co budziło stałą nieufność Kościoła, i co również zdaniem dyskutantów stwarzało poważną trudność pogodzenia tych celów z zadaniami Akcji Katolickiej ${ }^{41}$.

L. Rościszewski przypomniał w związku z tym, że kwestia pracy katolickiej wśród robotników była przedmiotem dyskusji w stowarzyszeniu inteligencji katolickiej i była konsultowana ze środowiskiem lubelskim. Na stawiane w tej sprawie pytania, ks. A. Szymański, autorytet w dziedzinie socjologii, odpisał, że katolicki program socjalny w kwestii robotniczej nie został jeszcze w Polsce skonkretyzowany i zachęcał do dyskusji. L. Rościszewski relacjonował dalej, że „inni katoliccy socjologowie w tej samej kwestii zapytywani zbyli nas milczeniem", po czym z żalem stwierdzał:

To wszystko dowodzi, że robotnicza kwestia socjalna nie dojrzała jeszcze w łonie Akcji Katolickiej do rozwiązania praktycznego i dlatego w programie kieleckiego DIAK została jeszcze pominięta ${ }^{42}$.

Ważnym przejawem działalności Akcji Katolickiej były organizowane przez nią obchody związane ze świętem patronalnym organizacji, uroczystością Chrystusa Króla. Organizacja obchodów w diecezji przebiegała w łączności z Naczelnym Instytutem Akcji Katolickiej (NIAK) w Poznaniu. Wiązało się to z dążeniem do nadania im charakteru ogólnopolskiej manifestacji katolickiej. I tak np. w $1932 \mathrm{r}$. uroczystość Chrystusa Króla obchodzono w parafiach diecezji kieleckiej pod hasłem wyznaczonym przez episkopat dla całej Polski, a była nim ,walka z bezwstydem i pornografią w druku i obrazku". W szczegółowych uwagach dla księży zalecano zwracanie uwagi nie tylko na negatywną stronę hasła, czyli konieczność zwalczania pornografii, także także na oddziaływanie pozytywne w formie propagowania dobrej prasy, która była ważnym orężem w walce $\mathrm{z}$ tym problemem. Zamieszczony na łamach KPD projekt organizacji uroczystości zawierał szczegółowy plan obchodów święta w parafii. Uwzględnione w nim zostały nie tylko elementy liturgiczne, ale także świeckie: wieczornica ze stosownym referatem, kolportaż publikacji katolickich, czy: „rozrzucanie między ludem jak największej ilości ulotek i broszur na temat szkodliwości pornografii”. Na wiecach organizowanych z tej okazji należało przyjąć tekst załączonej odezwy w której zapowiadano bezwzględną walkę z tą plagą ${ }^{43}$.

Sukcesem było przeprowadzenie diecezjalnego Kongresu Eucharystycznego w Jędrzejowie w dniach 23-26 sierpnia 1934 r. Szczegółowe sprawozdanie z jego przebiegu zamieszczono na łamach KPD. Kongres poprzedziły trzydniowe rekolekcje, osobne dni były poświęcone organizacjom męskim i kobiecym Akcji Katolickiej. Według sprawozdania przez wszystkie dni kongresu w różnych spotkaniach i mszach św. wzięło udział ok. 80 tys uczestników ${ }^{44}$.

W podejmowanych działaniach DIAK ściśle współpracował z NIAK w Poznaniu. Wśród przejawów tej współpracy możemy wymienić m.in. publikowa-

${ }^{41}$ Tamże, s. 15.

${ }^{42}$ Tamże, s. 6.

${ }^{43}$ Akcja Katolicka. Święto Chrystusa Króla, KPD 19 (1932) nr 10, s. 232-233.

${ }^{44}$ Sincerus, Szczegóty organizacyjne i przebieg pierwszego w diecezji kieleckiej Kongresu Eucharystycznego w Jędrzejowie, KPD, 21 (1934) nr 11, s. 280-288. 
nie informacji o organizowanych przez Naczelny Instytut kursach i zjazdach, zamieszczanie relacji ze spotkań kierowników diecezjalnych instytutów, czy podejmowanych wspólnych inicjatywach. Przykładem takiej działalności było opublikowanie sprawozdania z I Kursu Duszpasterskiego w Poznaniu w 1932 r., na którym ogłoszono dokument „Typ współczesnego duszpasterza”. Wskazywano w nim na konieczność kształcenia kleryków i duchownych w zagadnieniach dotyczących Akcji Katolickiej i stosowania osiągnięć współczesnej techniki takich jak film, przeźrocza czy radio, w oddziaływaniu wychowawczym ${ }^{45}$.

W 1934 r., na doszło do ujednolicenia statutów diecezjalnych Akcji Katolickich w całej Polsce. W konsekwencji formalnie znalazły się w niej tylko cztery kolumny ${ }^{46}$. Związek Inteligencji Katolickiej i Caritas pozostały poza jej strukturami. W dokumentach Diecezjalnej Rady Akcji Katolickiej w Kiecach te organizacje nazywano wyodrębnionymi, lub pomocniczymi. Podczas posiedzenia Rady 10 grudnia 1934 r., na którym omawiano plan pracy na kolejny rok przedstawiciele tych organizacji przedstawili swoje sprawozdania i informowali o planach, ale w opublikowanym protokole, konsekwentnie podkreślano ich pomocniczy charakter w stosunku do Akcji Katolickiej ${ }^{47}$.

W latach 1934-1937 był wydawany „Okólnik Akcji Katolickiej Diecezji Kieleckiej"48. Był to obszerny miesięcznik poświęcony bieżącym sprawom tej organizacji. Z tego powodu od 1935 r. na łamach KPD zmniejszyła się obecność materiałów odnoszących się do działalności Akcji Katolickiej. Dotyczyło to licznych sprawozdań, statystyk i zarządzeń DIAK. Wśród publikacji na łamach KPD zaczęła wówczas dominować problematyka dotycząc działalności charytatywnej.

W końcu lat 30-tych pojawiły się na łamach KPD bardziej pogłębione analizy dotyczące problemów socjalnych na kieleckiej wsi. Pierwszą taką próbą był referat ks. J. Kornobisa wygłoszony na zjeździe duszpasterskim w Kielcach 22 kwietnia 1937 r. Autor przypomniał, że diecezja kielecka po zmianach granic z 1925 r miała charakter rolniczy, stąd szczególna potrzeba zainteresowania się problemami wsi. Po raz pierwszy na łamach diecezjalnego pisma dla duchowieństwa padło stwierdzenie, że na wsi ,panuje już nie tylko bieda, ale nędza”. Referent przeprowadził obszerną analizę dochodów gospodarstw rolniczych opartą na danych z rocznika statystycznego i własnych obserwacjach, wskazywał na głodowe racje żywności, na jakie może pozwolić sobie większość mieszkańców wsi. Jako jedną z ważnych przyczyn tej sytuacji wskazywał konserwatyzm upraw chłopskich, przywiązanie do zboża, którego niska cena obniżała dochody rolników. Porównywał wydajność i dochodowość różnych upraw w Polsce i innych krajach europejskich. Zwracał też uwagę na przeludnienie wsi i brak możliwości emigracji zarobkowej do innych krajów, w tym także sezonowej. Nędza wsi generowała liczne problemy. Autor zauważał n.p., że o ile na wsi istnieje pozytywne

${ }^{45}$ Typ wspótczesnego duszpasterza, KPD ,19 (1932) nr 10, s. 248-250.

${ }^{46}$ K. Jeżyna, Akcja Katolicka w II Rzeczypospolitej, Lublin 1996, s. 37.

47 Sprawozdanie z czwartego dorocznego posiedzenia Rady Diecezjalnej Akcji Katolickiej w Kielcach 10 grudnia 1934 r., KPD, 22 (1935) nr 1, s. 10.

${ }^{48}$ M. Adamczyk, Prasa religijna Kielecczyzny $w$ dwudziestoleciu międzywojennym (Typologia, funkcje, modele), „Kieleckie Studia Bibliologiczne”, 2 (1994) s. 126. 
nastawienie do dzieci, traktowanych jako darmowa siła robocza w gospodarstwie, o tyle te same dzieci kiedy dorosną są traktowane jako konkurent do utrzymania, z którym należy się niekiedy nawet podzielić posiadaną ziemią. Było to częstym źródłem sporów rodzinnych ${ }^{49}$. Poruszane przez ks. J. Kornobisa problemy wsi pojawiały się w czasie dyskusji na konferencjach dekanalnych w okresie sede vacante po śmierci bpa A. Łosińskiego (30.04.1937).

Wraz z przyjściem nowego ordynariusza bpa Cz. Kaczmarka (24.05.1938), na łamach KPD zaczęły znów liczniej pojawiać się publikacje dotyczące Akcji Katolickiej. Początek rządów bpa Cz. Kaczmarka charakteryzował się znacznym ożywieniem w podejściu do zagadnień społecznych. Główną rolę w ich realizacji nowy ordynariusz wyznaczał właśnie Akcji Katolickiej. Wynikało to z jego doświadczeń wyniesionych z pracy duszpasterskiej w Belgii. Reprezentował nowy typ biskupa w nowej epoce. Był pełen zrozumienia dla kwestii społecznych i w tym obszarze nie bał się nowatorskiego podejścia do różnych wyzwań. Doceniał znaczenie ogólnopolskiego wymiaru podejmowanych działań, nie ograniczonych do jednej diecezji. Dlatego podejście do kwestii społecznych w ogóle i do Akcji Katolickiej w szczególności, zaczęło rysować się nieco inaczej niż za jego poprzednika.

Jeszcze w październiku 1938 r. biskup utworzył Wyższy Instytut Kultury Religijnej (WIKR), którego celem było podniesienie poziomu intelektualnego i moralnego elit katolickich diecezji. W deklaracji ideowej WIKR stwierdzano, że zbliża się czas, kiedy Polska będzie musiała wypełnić swoją „misję dziejową". Misją tą było budowanie jedności w narodzie, Kościele i między narodami regionu: „w tej części Europy przez Opatrzność umieszczonych”. W realizacji tej misji stały na przeszkodzie dwie ideologie. Chociaż nie zostały one wymienione z nazwy, należy sądzić, że chodziło o komunizm i faszyzm. Aby ten bój wygrać należało „wzmocnić ducha w narodzie”. Moralne wzmocnienie Polski było możliwe tylko przez oparcie na fundamencie cywilizacji chrześcijańskiej. Dalej autorzy deklaracji stwierdzali, że źródłem ,wielkiego działania jest wielka idea”. Idea ta została w deklaracji wyraźnie nazwana: „Mamy tę wielką ideę: jest nią idea narodowa, ożywiona uczuciem głębokiej miłości Ojczyzny”. Stając w obliczu różnych złudnych ideologii idea narodowa, aby przetrwać musiała się oprzeć na mocniejszym fundamencie, mogła nim być ,tylko ideologia chrześcijańska, którą daje nam Kościół katolicki”. Ta chrześcijańska ideologia od wieków zrosła się z polską duszą narodu i stanowiła istotny element ,naszej polskiej, narodowej kultury". Szczególna rola w przewodzeniu narodowi w spełnieniu jego misji przypadła inteligencji, która jednak, aby wypełnić swoje zadanie, musiała pogłębić swoją wiedzę religijną, poznać jej podstawy teologiczne i filozoficzne. Takiemu kształceniu inteligencji katolickiej miał służyć $\mathrm{WIKR}^{50}$. W deklaracji ideowej znajdujemy zatem wyraźne nuty nowych tendencji w polskim katolicyzmie właściwych dla końca lat 30-tych. Wzrost zaangażowania Kościoła kielec-

${ }^{49}$ J. Kornobis, Duszpasterz a nędza materialna i przeludnienie wsi, KPD, 24 (1937) nr 5, s. $146-158$.

${ }^{50}$ Założenia ideowe Wyższego Instytutu Kultury Religijnej w Kielcach, KPD, 25 (1938) nr 11, s. $342-343$. 
kiego dla realizacji kwestii społecznych, religijnych i politycznych w tym duchu pragnął rozwijać nowy biskup. Wybuch wojny przerwał zapoczątkowane prace.

W omawianym okresie możemy wyróżnić kilka etapów w podejściu w duchowieństwa diecezji do kwestii społecznych. W latach 1926-1929 kontynuowany był kierunek z lat 1917-1925 tworzenia w diecezji dla realizacji zadań społecznych takich organizacji, które zachowywały znaczną autonomię w stosunku do poza diecezjalnych ośrodków decyzyjnych. Związek biskupa A. Łosińskiego z tradycyjnym ruchem narodowym z początków XX w. wyznaczał ideowy kierunek preferowanych przez niego i diecezjalne duchowieństwo interpretacji, i rozwiązań w kwestiach społecznych. Rozwój idei ogólnopolskiej Akcji Katolickiej, której orędownikiem była Stolica Apostolska i znaczna część polskiego episkopatu skłonił biskupa A. Łosińskiego do otwarcia się na takie rozwiązanie. W latach 1930-1934 możemy zaobserwować podejmowane próby łączenia diecezjalnych doświadczeń z modelem ogólnopolskim. Należało do nich włączenie do struktur Akcji Katolickiej niektórych organizacji, które uważano za ważne dla rozwoju ruchu, a które równocześnie powinny zachować swoją odrębność organizacyjną wykraczającą poza strukturę czterech kolumn. Dotyczyło to m.in. Katolickiego Stowarzyszenia Inteligencji Katolickiej i Caritas. Na uwagę zasługuje też silna reprezentacja ziemiaństwa w Diecezjalnej Radzie Akcji Katolickiej. Po unifikacji statutów diecezjalnych Akcji Katolickich w 1934 r. rozpoczęto w diecezji kieleckiej przebudowę jej struktur w myśl tych założeń i eliminowanie lokalnych rozwiązań. Choroba biskupa w ostatnich latach życia nie sprzyjała intensywnym zmianom organizacyjnym i duszpasterskim. Przyjście do diecezji nowego ordynariusza bpa Cz. Kaczmarka oznaczało ożywienie w podejściu do kwestii społecznych w duchu rozwiązań typowych dla katolicyzmu polskiego z końca lat 30 . $\mathrm{XX}$ wieku.

słowa kluczowe: Kościół katolicki w Polsce; diecezja kielecka 1926-1939; kwestia społeczna; Akcja Katolicka; „Kielecki Przegląd Diecezjalny”

\section{BIBLIOGRAFIA}

\section{Źródła}

Akcja Katolicka. Święto Chrystusa Króla, „Kielecki Przegląd Diecezjalny”, 19 (1932) nr 10, s. 230-233.

Cieśliński S., O poparcie dla powstającej diecezjalnej „,Gazety Tygodniowej, „Kielecki Przegląd Diecezjalny", 17 (1930), nr 2, s. 38-39.

Dekret Erekcyjny, „Kielecki Przegląd Diecezjalny”, 18 (1931) nr 11, s. 263-264.

Gielniewski E., Groźne przestrogi dni majowych, „Kielecki Przegląd Diecezjalny”, 13(1926) nr 6-7, s. 111-117.

Gielniewski E., Stan religijno-moralny młodzieży w parafiach naszej diecezji na podstawie materiatów z ankiety duszpasterskiej z 1930 r., „Kielecki Przegląd Diecezjalny”, 18 (1931) nr 12, s. 307-315 
Gielniewski E., Wady naszego Ludu w świetle duszpasterskiej ankiety zebranej w poczatkach ub. roku, „Kielecki Przegląd Diecezjalny”, 18 (1931) nr 5, s. 141-144.

Instrukcja o konferencjach dekanalnych w roku 1930, „Kielecki Przegląd Diecezjalny”, 17 (1930) nr 1, s. 7-10.

Jabłoński W., O Sodalicje Mariańskie rzemieślniczo-mieszczański, „Kielecki Przegląd Diecezjalny", 18 (1931) nr 1, s. 13-16.

Kornobis J., Duszpasterz a nędza materialna i przeludnienie wsi, „,Kielecki Przegląd Diecezjalny", 24 (1937) nr 5, s. 146-158.

Krucjata Eucharystyczna w szkole powszechnej, „Kielecki Przegląd Diecezjalny”, 18 (1931) nr 1, s. 11-13.

Kursy dekanalne A. K., „Kielecki Przegląd Diecezjalny”, 19 (1932) nr 8-9, s. 200-205.

O przyjmowaniu świeckich prelegentów A. K., „Kielecki Przegląd Diecezjalny”, 19 (1932) nr 8-9, s. 199-200.

Projekt akcji religijno-społecznej dla duchowieństwa $w$ dobie obecnej, „Kielecki Przegląd Diecezjalny", 14, (1927), nr 3, s. 57-64.

Protokót z pierwszego posiedzenia Diecezjalnej Rady Akcji Katolickiej w Kielcach dnia 17 grudnia 1931 r., „Kielecki Przegląd Diecezjalny”, 19 (1932) nr 1, s. 8-17.

Regulamin Oddziatu Parafialnego Diecezjalnego Związu Towarzystw Dobroczynności „Caritas” w Kielcach, „Kielecki Przegląd Diecezjalny”, 18 (1931), nr 10, s. 229-230.

Sincerus, Szczegóły organizacyjne i przebieg pierwszego w diecezji kieleckiej Kongresu Eucharystycznego w Jędrzejowie, „Kielecki Przegląd Diecezjalny”, 21 (1934) nr 11, s. $280-288$.

Statut Diecezjalnego Instytutu Akcji Katolickiej w Kielcach, „Kielecki Przegląd Diecezjalny", 18 (1931) nr 11, s. 264-270.

Statut Stowarzyszenia Pań Miłosierdzia św. Wincentego A Paulo, „Kielecki Przegląd Diecezjalny", 18(1931) nr 8-9, s. 209-217.

Sprawozdanie z czwartego dorocznego posiedzenia Rady Diecezjalnej Akcji Katolickiej w Kielcach 10 grudnia 1934 r., „Kielecki Przegląd Diecezjalny”, 22 (1935) nr 1, s. 8-31.

Sprawozdanie z konferencji Ks. Dziekanów, „Kielecki Przegląd Diecezjalny”, 16 (1929), nr 12, s. 294-303.

Sprawozdanie z pierwszej konferencji pasterskiej kapłanów m. Kielc, „Kielecki Przegląd Diecezjalny", 14 (1927) nr 1, s. 25-27.

Synodus Dioecesana Kielcensis, Kielce 1927.

Typ wspótczesnego duszpasterza, „Kielecki Przegląd Diecezjalny”, 19 (1932) nr 10, s. 247250.

Założenia ideowe Wyższego Instytutu Kultury Religijnej w Kielcach, „Kielecki Przegląd Diecezjalny", 25 (1938) nr 11, s. 342-343.

Zjazd diecezjalny Księży Dziekanów, Wicedziekanów i delegatów dekanalnych, „Kielecki Przegląd Diecezjalny”, 17 (1930) nr 6-7, s. 191-198.

Z komisji Akcji Katolickiej, „Kielecki Przegląd Diecezjalny”, 19 (1932) nr 1, s. 4-7.

Z komisji Akcji Katolickiej. Protokót z drugiego posiedzenia Diecezjalnej Rady A. K. w Kielcach dnia 29 listopada 1932 r., „Kielecki Przegląd Diecezjalny”, 20 (1933) nr 1, s. 7-24.

Z Komisji Akcji Katolickiej. Wykaz osób na Tydzień A. K., „Kielecki Przegląd Diecezjalny", 19(1932) nr 6-7, s. 167-168.

Znaczenie zarządzeń Komisji Akcji Katolickiej, „Kielecki Przegląd Diecezjalny”, 18 (1931) nr 1, s. 1 . 


\title{
Opracowania
}

Adamczyk M., Prasa religijna Kielecczyzny $w$ dwudziestoleciu międzywojennym (Typologia, funkcje, modele), „Kieleckie Studia Bibliologiczne”, 2 (1994) s. 111-128.

Bujak G., Praca społeczna $w$ diecezji kieleckiej $w$ świetle publikacji na łamach miesięcznika dla duchowieństwa „Przeglad Diecezjalny” z lat 1917-1925, „Archiwa Biblioteki i Muzea Kościelne", 105 (2016) s. 5-24.

Jeżyna K., Akcja Katolicka w II Rzeczypospolitej, Lublin 1996.

Krasowski K., Biskupi katoliccy II Rzeczypospolitej. Stownik biograficzny, Poznań 1996.

Niparko R., Akcja Katolicka, w: „Encyklopedia Katolicka”, t. 1, Lublin 1985, kol. 227 233.

\section{SOCIAL WORK IN THE DIOCESE OF KIELCE, ACCORDING TO PUBLICATIONS IN KIELECKI PRZEGLĄD DIECEZJALNY IN THE YEARS 1926-1939. AN OUTLINE OF THE CHANGES}

\begin{abstract}
Summary
The author discusses the most important publications on social issues published in the monthly journal Kielecki Przegląd Diecezjalny in the years 1926-1939. The paper presents the changes that took place in the attitude of the priests to these issues. It demonstrates the process of creating local solutions in this sphere and gradual transition from them to a nationwide vision of the Church, based on a holistic approach to social issues such as the Catholic Action.
\end{abstract}

Keywords: the Catholic Church in Poland; the diocese of Kielce 1926-1939; a social issue; the Catholic Action; Kielecki Przegląd Diecezjalny 